This is the final Accepted Manuscript (version after refereeing). Please cite this article as follows:

Cândido, C.J.F., Coelho, L.M.S., and Peixinho, R.M.T. (2021) Why firms lose their ISO 9001 certification: Evidence from Portugal. Total Quality Management and Business Excellence, 32(5-6), 632-651. http://dx.doi.org/10.1080/14783363.2019.1625266.

DOWNLOAD FREE COPY of the publisher's version here:

https://www.tandfonline.com/eprint/wUkqgwthDWKyIDRhAU5J/full?target=10.1080/14783363.2019.1625266.

Please click only once as the number of free downloads is limited.

The Version of Record of this manuscript has been published and is available in Total Quality Management \& Business Excellence, 2021,

https://www.tandfonline.com/doi/full/10.1080/14783363.2019.1625266.

\title{
Why firms lose their ISO 9001 certification: Evidence from Portugal
}

\section{Carlos J.F. Cândido}

CEFAGE-UAlg and Faculdade de Economia, Universidade do Algarve, Faro, Portugal.

\section{Luís M.S. Coelho}

CEFAGE-UAlg and Faculdade de Economia, Universidade do Algarve, Faro, Portugal.

\section{Rúben M.T. Peixinho}

CEFAGE-UAlg and Faculdade de Economia, Universidade do Algarve, Faro, Portugal.

\begin{abstract}
More than one million certified companies must choose, every three years, whether to renew or to withdraw from ISO 9001 certification. This paper investigates whether ISO 9001 decertification decision is driven by economic motivations. Using standard event-study methods, the paper looks into this question by comparing the abnormal performance of a sample of Portuguese firms that lose their certification with that of similar, non-event, firms. The paper finds no statistically significant differences in the economic performance of these two sets of firms in their post-ISO certification period. Such evidence suggests that economic underperformance is not the reason why companies are ISO-decertifying and further suggests that the decision to decertify is economically irrelevant. The study advances possible explanations for this (ir)relevancy and puts forwards implications for theory and for the ISO 9001 governance system. The governance system must change in order to increase the economic benefits that organizations can expect to gain from ISO (re)certification. This is the first study assessing the impact of ISO 9001 certification on firms that subsequently lost the certificate.
\end{abstract}

Keywords: decertification, economic performance, event study, ISO 9001, small and medium-sized enterprises. 


\section{Introduction}

ISO 9001 is a quality management standard published, in its first version, in 1987, by the International Organization for Standardization. Companies can adopt the latest version of the standard without external supervision. Yet, in order to be awarded an ISO 9001 certificate, they must have their quality system audited by an independent agency (Castka, Prajogo, Sohal \& Yeung, 2015; Miller, Jayaram \& Xu, 2018). Many organizations chose the latter option, because they believe that 'an independent confirmation of conformity adds value' (International Organization for Standardization [ISO], 2012). Consistent with this belief, most studies have concluded that ISO 9001 certification has a significant impact on performance (e.g., Aba, Badar \& Hayden., 2016) and on firms' competitive advantage (Naveh \& Marcus, 2005).

In recent years, however, certification withdrawal (decertification) has become a widespread phenomenon. Available data shows that around 60 thousand firms lose their ISO 9001 certification around the world every year. The number of withdrawals has actually grown at an annual average rate of 25\% (International Organization for Standardization [ISO], 2014). In general, decertification may result from the loss of interest on certification or from the inability of the firm to comply with the standards. The empirical evidence on the specific reasons justifying the increasing number of withdrawals is, however, scant. In particular, only four academic articles, searchable in research databases, look into somewhat related issues (Lo \& Chang, 2007; Alič, 2014; Sansalvador \& Brotons, 2015; Cândido, Coelho \& Peixinho, 2016). These studies point to the fact that decertification occurs when firms do not experience a certain economic benefit upon their ISO 9001 certification. Results, however, are preliminary at best. In fact, no study has yet investigated how ISO 9001 certification affects performance contingent on whether firms decide to renew their certification status. To this point, recent research by Alič (2014) stresses that we still do not know 'why organizations choose to give up certification', an idea also raised in the earlier paper by Lo \& Chang (2007).

The present paper aims at shedding light on this important topic with the help of a sample of 278 Portuguese non-listed small and medium-sized enterprises (SMEs) that had to decide in 2011 whether to renew or not renew their initial ISO 9001 certification. Portugal is an interesting European country to study since it experienced a fast growth in the number of ISO 9001 certified companies in the late 1990's and in the beginning of the 21th century. Yet, in recent years, the number of certified firms in the country has plummeted (ISO, 2014).

Using standard event-study methodology, this paper investigates whether decertification is contingent on the economic performance that follows the initial ISO certification. The empirical evidence strongly rejects this notion. In particular, the event-study results show that companies that end up decertifying exhibit a level of economic performance in the postcertification period statistically similar to that of comparable firms that continue ISOcertified. Such conclusion is robust to various metrics of economic performance, and holds after considering different methodological choices for implementing the event-study. Hence, to the best of the authors' knowledge, this is the first paper that empirically shows that economic underperformance is unlikely to be the key motivation for decertification, which constitutes a novel contribution to the literature since the few existing paper that address somewhat related topics typically argue otherwise.

The rest of the paper is organized as follows. Section 2 reviews the previous literature and presents the research hypothesis. Section 3 summarizes and explains the research methodology whilst section 4 presents the data. Sections 5 presents the results. Section 6 concludes the paper. 


\section{Literature review and research hypothesis}

The literature debating the reasons leading up to ISO 9001 decertification is still in its infancy. A thorough search conducted in the EBSCO Host Research Databases, using several distinct keywords, reveals that there are only four studies currently available on the subject. Two additional studies, not included in the databases available to us, were kindly brought to our attention by a reviewer. All of these papers are listed on Table 1 together with their main conclusions in what regards firms' potential reasons for decertification.

Table 1 . Reasons why companies abandon certification

\begin{tabular}{|c|c|}
\hline Study & Reasons for abandoning ISO 9001 \\
\hline $\begin{array}{l}\text { Lo \& Chang } \\
(2007)\end{array}$ & $\begin{array}{l}\text { 1. Time consumed with certification and costs } \\
\text { 2. Paperwork load } \\
\text { 3. ISO } 9001 \text { is 'merely the absolute minimum requirement for an enterprise' } \\
\text { 4. Lack of ISO } 9001 \text { contribution to financial performance }\end{array}$ \\
\hline Alič (2014) & $\begin{array}{l}\text { 1. Negative effects of ISO } 9001 \text { implementation (or improper implementation) } \\
\text { 2. Lower marketing attractiveness of ISO } 9001\end{array}$ \\
\hline $\begin{array}{l}\text { Sansalvador \& } \\
\text { Brotons }(2015)\end{array}$ & $\begin{array}{l}\text { 1. Results bellow what was expected from certification } \\
\text { 2. Savings that abandonment would generate }\end{array}$ \\
\hline $\begin{array}{l}\text { Cândido et al.'s } \\
(2016)\end{array}$ & $\begin{array}{l}\text { 1. Company has already internalized the benefits of certification } \\
\text { 2. Renewal costs are higher than the benefits } \\
\text { 3. Belief that the certification body will not renew the certificate }\end{array}$ \\
\hline $\begin{array}{l}\text { Kafel \& } \\
\text { Nowicki (2014), } \\
\text { Simon \& Kafel } \\
(2018)\end{array}$ & $\begin{array}{l}\text { 1. Financial problems within the organization combined with recertification cost } \\
\text { 2. Improvement in processes occur in the beginning of the certification period } \\
\text { 3. Option for other more demanding standards } \\
\text { 4. Customers no longer demand ISO } 9001 \text { certification } \\
\text { 5. Other }\end{array}$ \\
\hline
\end{tabular}

Lo \& Chang (2007) study the reasons why certified firms may fail to maintain ISO certification, suggesting that 'the expenditure of time and cost required to maintain ISO 9000 certification would discourage those companies that did not see significant benefits from continuing to maintain certification'. They look at this issue with the help of 171 Taiwanese firms (eleven of which lost their certification) and by performing a multivariate analysis of covariance based on sixteen different types of variables that capture the perception of firm performance. Most of their results are not statistically significant. Yet, there seems to be evidence to suggest that firms that keep their ISO certification are different from those that do not in what regards issues like quality awareness, documentation, lower defect rates, complaints and external image.

Alič (2014) aims to study the 'future functioning and financial performance' of organizations that lost their ISO 9001 certificate. According to this author, losing ISO 9001 certificate can lead to a performance decline because of (1) lack of external audits and 'pressure to obey the standards', (2) decreasing management support towards quality, (3) decreasing organizational interest in quality management systems, (4) 'absence of quality management praxes', and (5) negative impact on firm reputation of a cancelled certificate. Drawing on this intuition, Alič (2014) performs a longitudinal survey based on a sample of 291 organizations from several industries in Slovenia that lost their ISO 9001 certificate in the period 2009 to 2012. Results suggest that the loss of ISO certification leads to a plunge in performance. In particular, Alič (2014) shows that most of the sample firms experience a decline in their financial results in the post-decertification period, with up to $45 \%$ closing down within the four-year period considered in this study. The author concludes that termination of ISO 9001 certification may be viewed as an early external signal of possible 
future problems in the organization.

Sansalvador \& Brotons (2015) take a different approach and try to uncover the value of the put option that abandoning ISO certification represents. In particular, after reviewing the literature, Sansalvador \& Brotons (2015) conclude that not all companies benefit from certification because 'there are different levels of internalization of the standards, which affects how companies implement them, and ultimately, firms' results'. As such, for some firms, the option to give up ISO certification must be valuable. The authors test this conjecture using a convenience sample of thirteen Spanish companies and a 'fuzzy real options' approach. Although their result cannot be generalized, the authors show that the value of a certified company (i.e. that has the option to abandon certification) is higher than the value of a noncertified company.

Cândido et al. (2016) look at how the loss of the ISO 9001 certification affects the decertified firms' financial performance. The authors use an event study methodology, which matches a sample of 143 decertified Portuguese companies from several industries with similar non-event companies and compare their performance over different periods of time. Cândido et al. (2016) conclude that ISO decertification does not lead to any significant abnormal performance since there are no statistically significant differences in the performance of these firms as measured by return-on-assets, return on sales or sales growth.

Kafel \& Nowicki (2014) aim to explore the reasons for ISO 9001 withdrawal. The authors perform an analysis of seven case studies and end up concluding that cost considerations and the absence of benefits are the two main reasons for ISO 9001 withdrawal. In a subsequent study, Simon \& Kafel (2018) use data from 130 companies that voluntarily abandoned ISO 9001, and are able to identify a larger list of possible reasons for withdrawal. Yet, their conclusions suggest that the main motivations for decertification are, in fact, similar to those uncovered in the 2014 study.

The previous paragraphs summarize the scant evidence currently available on the relation between firm performance and loss of ISO 9001 certification. Three main ideas seem to emerge from this literature. First, decertification happens when the companies do not perceive to benefit from being ISO certified. Second, there is some evidence to suggest that certification creates value since it generates an option to abandon such quality distinction. Third, there are some conflicting results on how decertification actually impacts firm performance. On the one hand, evidence from Slovenia suggest that such event leads to a decline in financial results and seems to be an important signal about future problems that may lay ahead. In contrast, recent Portuguese evidence disputes such notion in the sense that ISO-decertified firms exhibit no abnormal performance in the post-decertification period.

The current paper adds to this discussion by addressing a different question. In particular, it examines to what extent the loss of ISO certification is driven by a lack of improvement in performance resulting from the initial certification event. Thus, this paper's main research hypothesis can be framed as follows:

H1: The post-certification abnormal performance of the firms that lose the certificate is similar to that of companies that remain ISO certified.

H1a: The post-certification abnormal performance of the firms that lose the certificate is lower than that of companies that remain ISO certified.

The intuition for this paper's main research hypothesis is straightforward. Theory suggests that ISO certification leads to an improvement in performance, which is lasting and accrues over time (Simmons \& White, 1999; Chow-Chua, Goh \& Wan, 2003; Mokhtar, Karbhari \& Naser, 2005; Naveh \& Marcus, 2007; Dick, Heras \& Casadesús, 2008; Nair \& 
Prajogo, 2009; Pantouvakis \& Dimas, 2010; Prajogo, 2011; Gómez, Fontalvo \& Vergara, 2013; Psomas, Pantouvakis \& Kafetzopoulos, 2013; Fatima, 2014; Psomas \& Kafetzopoulos, 2014; Chatzoglou, Chatzoudes \& Kipraios, 2015; Ochieng, Muturi \& Njihia, 2015; Islam, Habes, Karim \& Agil, 2016). The recent raise in the number of ISO decertification events, however, questions this view. In particular, it is conceivable that only some firms end up reaping the benefits suggested by extant theory in the post-ISO certification period. If that were to be the case, some ISO-certified firms would have an incentive to drop such certification given that it is costly, requires dedicated resources and yields no tangible benefits to them. Under this set up, some firms would like to remain ISO-certified whenever recertification is up but others would not. This paper directly examines this issue, thus contributing to our knowledge on how firm performance relates to the loss of ISO 9001 certification.

\section{Methodology}

As discussed in the previous section, this paper aims at investigating whether loss of ISO 9001 certification can be explained by an unsatisfactory level of performance resulting from the initial ISO certification. This question is explored by employing an accounting-based event-study (Barber \& Lyon, 1996). The event of interest is thus certification of the firm. As such, the year of certification is defined as the event-year (henceforth denoted as year $t$ ). The paper then tracks the abnormal performance of the firms of interest over three different periods of time around the event date, i.e., $[\mathrm{t}-1, \mathrm{t}],[\mathrm{t}-1, \mathrm{t}+1]$ and $[\mathrm{t}-1, \mathrm{t}+2]$. Importantly, the period $[t-1, t+3]$ may not be considered in the analysis since the computation of abnormal performance must ensure that each period begins before the certification date and ends while the firm is still certified. During year $t+3$ the certification status of all the sample firms is reassessed and each company may or may not continue certified.

Running an event-study requires employing some measurement of abnormal performance. Barber \& Lyon (1996) explain why resorting to operating income for such purpose is better than using earnings figures as advocated by some early authors (e.g., Healy \& Palepu, 1988; Healy \& Palepu, 1990; Asquith, Healy \& Palepu, 1989). Hence, this paper employs return-on-assets (ROA) as its main economic performance measure. In line with Barber \& Lyon (1996), ROA is defined as the ratio of earnings before interest and taxes (EBIT) to the average of beginning- and ending-period year book value of total assets. This paper tests the robustness of the main findings by employing two additional measures of performance. The first is the return-on-sales (ROS), which is computed by comparing the EBIT figure with that of the total operating revenue. The higher the value of this ratio, the more cost-efficient the firm is. ROS is an interesting measure since it does not have problems related to 'historic cost' given that is based in figures coming only from the income statement. The second robustness measure is the rate of growth in sales. It is defined as the percentage variation in the operating revenue of the firm over two consecutive years. Albeit not a strict measure of economic performance, growth in sales is an important additional measure since it sheds light on how ISO certification impacts firm's market share, a key issue raise by Corbett, Montes-Sancho \& Kirsch (2005).

An event-study also requires defining a model of expected performance. Barber \& Lyon (1996) test several potential alternatives and, in the end, favor using a model that matches the relevant sample firms with control firms on both size and pre-event performance. This is the only combination that yields well-specified test statistics in all situations that were considered. As such, this paper defines the expected operating performance of sample firm $i$ over period $l$ as: 


$$
E\left(P_{i, t, l}\right)=P_{i, t}+\left(P I_{i, t+l}-P I_{i, t}\right)
$$

where, $P_{i, t}$ is the actual performance of firm $i$ in time $t$ and $P I_{i, t}$ is the performance of the control group in year $t$.

Employing Equation (1) above requires identifying a suitable control group of firms. Drawing on the previous literature, this paper deals with this issue by finding companies of similar risk that do not become ISO-certified in year $t$. In particular, in line with Barber \& Lyon (1996), control companies are matched with the sample firms using a three-step approach. First, this paper identifies suitable candidates for each sample firm $i$ based on size. These are all comparable firms listed in the AMADEUS database with book value of assets in year $t-2$ between $70 \%$ and $130 \%$ of that of the sample firm in the same year. Second, candidates are excluded based on pre-event performance, i.e., all match firms with a ROA that falls outside the $90 \%$ to $110 \%$ interval of the ROA of the sample firm $i$ they are paired with in year $t-2$ are eliminated. In the final step, this study eliminates all potential candidates that do not have enough data to be included in the event-study. In particular, matching firms must have the required accounting data available in year $t+1$ and $t+2$ since Barber \& Lyon (1996, p. 377) recommend holding the matching firm portfolio constant over time. The final number of companies matched to each sample firm $i$ by this procedure is variable. ${ }^{1}$ Drawing on Barber \& Lyon (1996, p. 369), when appropriate, this paper employs medians as proxy for the performance of the control group in year $t$.

The final step of the event-study is testing whether the abnormal performance of the sample firms is significantly different from zero. This paper computes the abnormal performance of sample firm $i$ over period $l$ as follows:

$$
A P_{i, t, l}=P_{i, t+l}-E\left(P_{i, t, l}\right)
$$

where $P_{i, t+l}$ is the actual performance of firm $i$ in time $t+l$, and $E\left(P_{i, t, l}\right)$ is given by Equation (1). In line with Barber \& Lyon (1996), this paper uses the nonparametric Wilcoxon signedrank test as the main metric for detecting the abnormal performance of the sample firms. In fact, these authors conclude that such test is more powerful than its $t$-test parametric counterpart in all the situations they consider. Yet, for completeness, parallel results using $t$ tests are also reported. ${ }^{2}$

\section{Data}

This paper starts by locating firms operating at Portugal that get their initial ISO certification in 2008. The list is manually compiled using data from the Institute of Portuguese Accreditation and Certification (IPAC). As shown in Table 2, this first step yields a total 719 firms. Next, this paper matches such list with the data available in the AMADEUS database, which is provided by Bureau van Dijk and contains the financial statements of 21 million listed and privately held firms in Europe. A total of 441 firms had to be dropped from the final sample at this stage either because they could not be found on AMADEUS or because they did not have all the required data to perform the statistical analysis. The final sample used in this paper thus encompasses 278 firms. As shown in Table 2, 255 of these firms are continuously ISO-certified throughout the sample period while 23 are decertified in 2011.

\footnotetext{
${ }^{1}$ The matching procedure yields individual control portfolios that have between 2 and 859 matched firms.

2 The Shapiro-Wilk test always rejected the hypothesis that abnormal performance is normally distributed with $p$-values below 0.01 in all the scenarios this paper explores.
} 
Table 2. Defining the sample

\begin{tabular}{lc}
\hline & Frequency \\
\hline Cases identified in IPAC's database & 719 \\
Cases not found or with insufficient data on AMADEUS & 441 \\
Final sample & 278 \\
Cases that are continuously ISO certified & 255 \\
Cases for which certification is lost in 2011 & 23 \\
\hline
\end{tabular}

All the firms in the final sample are incorporated at Portugal as a limited liability company (i.e., "Sociedade por Quotas" or "Sociedade Anónima"). Furthermore, they are all SMES (European Union Recommendation 2003/361), reporting nonconsolidated financial statements. Forty-seven (or $16.9 \%$ of the total) compete in the wholesale trade sector, 36 (or $13.0 \%$ of the total) are in the construction sector, and 18 (or $6.5 \%$ of the total) are manufacturing firms. The rest of the sample is evenly spread across multiple economic sectors.

Table 3 presents descriptive statistics for the 278 sample firms employed in this study and parallel figures for the population of comparable Portuguese companies available on the AMADEUS database. ${ }^{3}$ Variables in Table 3 are winsorized at the first and the 99th percentiles to minimize the influence of extreme outliers.

In Panel A, statistics are for the 2007 fiscal-year, which is the last year when firms in the sample are not ISO certified. As can be seen, the sample firms are significantly larger (as measured by the book value of assets) than the comparable Portuguese firms in the AMADEUS database. This holds both for mean and median figures since the $p$-value of the $t$ test and the Wilcoxon-Mann-Whitney test for this variable are significant at normal levels $(1 \%, 5 \%$ and $10 \%)$. Furthermore, Panel A of Table 3 suggests that the sample firms are less levered, although less able to cope with interest payments on their debt than their AMADEUS equivalents. Also, there is some (albeit weak) evidence that the sample firms are less liquid than the population of firms they are being compared to. More importantly, this paper finds no evidence to suggest that the sample firms are able to deliver higher economic or cash-flow performance in the year leading to their ISO certification vis-à-vis that of their AMADEUS counterparts. In fact, none of the $t$ - and Wilcoxon-Mann-Whitney tests for the ROA and Cashflow (CF) variables are significant at normal levels.

Panel B of Table 3 presents parallel evidence for the 2009 fiscal year-end, i.e. the year following the certification event. As can be seen, the results are not very different from those discussed above. This paper again finds that the sample firms are larger than their AMADEUS counterparts, a result that is statistically backed by the results of both the $t$ - and Wilcoxon-Mann-Whitney test for the book value of total assets. Also, Panel B suggests that liquidity is higher within the businesses that are part of the population of firms in the AMADEUS database, a result that holds for both parametric and non-parametric tests. More importantly, Panel B of Table 3 again shows that the sample firms are not yielding better

\footnotetext{
${ }^{3}$ On average, 32,000 firms are considered when computing the statistics for the AMADEUS population presented in Table 3.
} 
cash-flow or economic performance than the AMADEUS firms. In fact, the mean (median) difference in CF between sample and AMADEUS firms is $0.0(-0.01)$, not significant at even the $10 \%$ level. Similarly, the mean (median) difference in ROA is $0.6 \%(0.0 \%)$, again not statistically significant at normal levels. Finally, in contrast to the 2007 results, Panel B suggests that sample and AMADEUS counterparts exhibit similar levels of indebtednesses since the tests for differences in means and medians for leverage are now not significant.

Table 3. Summary statistics

\begin{tabular}{ccccccc}
\hline \multirow{2}{*}{ Variable } & \multicolumn{2}{c}{ Sample Firms } & \multicolumn{2}{c}{ Amadeus Population } & \multicolumn{2}{c}{ Diff. (Sample-Amadeus) } \\
& Mean & Median & Mean & Median & Mean & Median \\
\hline TA $(\epsilon m)$ & 7.3 & 3.4 & 1.7 & 0.4 & $5.6^{* * *}$ & $3.0^{* * *}$ \\
LEV & $29.4 \%$ & $30.2 \%$ & $33.8 \%$ & $31.3 \%$ & $-4.4 \% * * *$ & $-1.1 \% * *$ \\
LIQ & 1.5 & 1.3 & 2.4 & 1.4 & $-0.9 * * *$ & -0.1 \\
INT_COV & 0.3 & 0.2 & 0.2 & 0.1 & $0.1 * * *$ & $0.1 * * *$ \\
CF & 0.08 & 0.07 & 0.09 & 0.07 & -0.01 & 0.0 \\
ROA & $5.6 \%$ & $4.8 \%$ & $5.4 \%$ & $4.5 \%$ & $0.2 \%$ & $0.3 \%$ \\
\hline TA $(\epsilon m)$ & 7.9 & 3.5 & 1.8 & 0.4 & $6.1 * * *$ & $3.1 * * *$ \\
LEV & $32.8 \%$ & $33.2 \%$ & $34.7 \%$ & $32.5 \%$ & $-1.9 \%$ & $0.7 \%$ \\
LIQ & 1.8 & 1.3 & 2.9 & 1.5 & $-1.1 * * *$ & $-0.2 * *$ \\
INT_COV & 0.3 & 0.2 & 0.2 & 0.1 & 0.1 & $0.1 * * *$ \\
CF & 0.07 & 0.05 & 0.07 & 0.06 & 0.0 & -0.01 \\
ROA & $4.1 \%$ & $3.3 \%$ & $3.5 \%$ & $3.3 \%$ & $0.6 \%$ & $0.0 \%$ \\
\hline
\end{tabular}

Notes: ${ }^{* *},{ }^{* *}$ Significant at the 5 and 1 percent levels, respectively. TA: total assets in millions of euros. LEV: leverage proxy (total debt/total assets). LIQ: liquidity proxy (current assets/current liabilities). INT_COV: bankruptcy risk proxy (interest expense/EBITDA). CF: cash-flow proxy (cash-flow/ average of beginning- and ending-period book value of total assets). ROA: return on assets (EBIT/average of beginning- and ending-period book value of total assets).

\section{Results}

Table 4 summarizes this paper's main findings. To help interpret the results consider the case when ROA is the performance measure, the 'Initial Year' is 2007 and the 'Final Year' is 2008. For this combination of inputs, the first column of Table 4 (i.e., "All Firms") shows the abnormal performance of the full sample based on ROA in 2008 when the base year is 2007 . As can be seen, the median figure is $0.2 \%$, which suggests that the actual performance of the firms in the sample (as portrayed by ROA) exceeds that which one could reasonably expect over the period of interest in the absence of the ISO certification event. Yet, such abnormal performance is not statistically significant since the $p$-value of the associated Wilcoxon signed-rank test (i.e., this paper's main statistical test) is 0.56. A similar pattern arises when one considers counterpart parametric results. In particular, the mean abnormal performance is $0.1 \%$ and the corresponding $t$-test is not significant at normal levels. Hence, together, the statistical evidence now discussed suggests that the ISO certification event does not lead the sample firms to experience an especially high or low performance as compared to that one could reasonably expect in the absence of such an event.

Table 4 sheds light on our main research hypothesis by presenting the abnormal 
performance of the sample firms when they are split into two groups: the ISO firms and the LOST_ISO firms. The first set is for the 255 companies that continue ISO certified after 2011; the second is composed of the 23 that decertify in the same year. As can be seen, ISO firms exhibit a median abnormal performance of $0.18 \%$ in 2008 when 2007 is the base year and ROA is employed as the performance measure. The matching figure for the Lost_ISO firms is $0.56 \%$. At face value, these results would suggest that decertified firms actually have a better performance than their continuously certified equivalents. Yet, none of the corresponding Wilcoxon signed-rank tests is statistically significant at normal levels, leading to the conclusion that none of these two groups of firms experiences a significant abnormal performance as measured by ROA in the 2007-2008 period. Actually, this is not the entire (or most important) story. Table 4 shows that, in the context under analysis, the Wilcoxon ranksum test for differences in median performance between ISO and Lost_ISO firms is not significant at conventional levels. In particular, when ROA is the performance metric, and the 'Initial Year' is 2007 and the 'Final Year' is 2008, the $p$-value of this test is 0.89 , thus not statistically significant. This is an important finding since it directly provides empirical evidence in support of this paper's main research question. To be precise, this paper's evidence suggests that ISO and Lost_ISO firms exhibit similar economic performance following their initial certification. Hence, it seems that the decertification event is not driven by differences in performance resulting from the initial ISO certification.

Close inspection of the full range of results presented in Panel A of Table 4 leads one to realize that the conclusions presented above are pretty general. In effect, when control firms are matched on size and ROA and ROA is employed as performance metric none of the statistical tests is significant at normal levels, a result that holds irrespective of the test period one considers.

Table 4 also shows what happens when the ROS is used as an alternative economic performance measure. When this is the case, this paper finds a significant Wilcoxon signedrank test for the full sample (i.e. "All Firms" column) for the 2007-2009 and 2007-2010 event-periods. Importantly, for these periods, the median abnormal performance computed via the event-study is positive (3.2\% and $4.6 \%$, respectively), which suggests that ISOcertification leads the sample firms to become more cost-efficient once the certification process is complete. Parallel results using means are not significant, with Barber \& Lyon (1996) showing that non-parametric tests are more reliable in this context, however. Results are very similar when one considers the ISO and Lost_ISO groups separately. In particular, Panel B of Table 4 shows that both set of companies enjoy positive and significant median abnormal performance in the periods 2007-2009 and 2007-2010. Yet, very importantly, none of the Wilcoxon rank-sum tests for differences in median performance reported in Panel B are significant at even the $10 \%$ level (a similar conclusion holds for the corresponding parametric $t$-tests). Hence, in line with Panel A, the evidence in Panel B of Table 4 suggests that the level of abnormal performance (as measured by ROS) in post-ISO certification period is similar for firms that continue to be certified in 2001 and those that lose their certification in that same year.

Table 4 also summarizes the results when growth in sales is the performance measure. As can be seen in Panel C, with the exception of the 2007-2008 window, this paper always find $t$ - and Wilcoxon signed-rank tests that are significant at normal levels when the full sample is considered. Moreover, in this context, medians and means are always negative, leading to the conclusion that, in general, the growth rate in sales plummets after sample firms become ISO-certified. ${ }^{4}$ Panel $\mathrm{C}$ of Table 4 also presents evidence on the abnormal

\footnotetext{
${ }^{4}$ One possible explanation links to the fact that 2008 was the first year of the world-wide financial crises
} 
performance of ISO and Lost_ISO firms separately. As can be seen, the former seem to sustain very significant losses in their growth rate of sales after getting their ISO certification, a conclusion that is particularly clear in the 2007-2009 and 2007-2010 periods. In contrast, Panel C of Table 4 shows that the $p$-values for the $t$ - and Wilcoxon signed-rank tests for the Lost_ISO companies are always above the $10 \%$ level, which suggest that certification does not affect their growth in sales over and above what one could expect given risk. Interestingly, in line with this paper's main conclusion for ROA and ROS, Panel C of Table 4 suggests that ISO and Lost_ISO firms present similar economic performance when growth of sales is employed to conduct the analysis. Once again, none of the Wilcoxon rank-sum tests for differences in medians or their counterpart $t$-test for differences in medians are significant at normal levels.

Table 4. ISO certification and abnormal Performance - matching by SIZE and ROA

\begin{tabular}{|c|c|c|c|c|c|c|c|c|c|}
\hline \multirow{3}{*}{$\begin{array}{c}\text { Initial } \\
\text { Year }\end{array}$} & \multirow{3}{*}{$\begin{array}{l}\text { Final } \\
\text { Year }\end{array}$} & \multicolumn{2}{|c|}{ All firms } & \multicolumn{2}{|c|}{ ISO Firms } & \multicolumn{2}{|c|}{ LOST_ISO Firms } & \multicolumn{2}{|c|}{ (ISO - LOST.) } \\
\hline & & AP & AP & AP & AP & AP & AP & AP & AP \\
\hline & & Mean & Median & Mean & Median & Mean & Median & Mean & Median \\
\hline \multicolumn{10}{|c|}{ Panel A: operating performance is measure by $R O A$} \\
\hline \multirow[t]{2}{*}{2007} & 2008 & $0.10 \%$ & $0.20 \%$ & $0.11 \%$ & $0.18 \%$ & $-0.45 \%$ & $0.56 \%$ & $0.56 \%$ & $-0.38 \%$ \\
\hline & & 0.88 & 0.56 & 0.81 & 0.54 & 0.65 & 0.95 & 0.60 & 0.89 \\
\hline \multirow[t]{2}{*}{2007} & 2009 & $-0.20 \%$ & $0.40 \%$ & $-0.22 \%$ & $0.38 \%$ & $0.13 \%$ & $0.27 \%$ & $-0.35 \%$ & $0.11 \%$ \\
\hline & & 0.70 & 0.86 & 0.68 & 0.92 & 0.92 & 0.84 & 0.79 & 0.90 \\
\hline \multirow[t]{2}{*}{2007} & 2010 & $-0.20 \%$ & $0.10 \%$ & $-0.24 \%$ & $0.03 \%$ & $-0.06 \%$ & $1.52 \%$ & $-0.18 \%$ & $-1.49 \%$ \\
\hline & & 0.72 & 0.96 & 0.73 & 0.91 & 0.95 & 0.30 & 0.87 & 0.57 \\
\hline \multicolumn{10}{|c|}{ Panel B: operating performance is measure by ROS } \\
\hline \multirow[t]{2}{*}{2007} & 2008 & $1.80 \%$ & $0.30 \%$ & $1.22 \%$ & $0.17 \%$ & $7.73 \%$ & $1.11 \%$ & $-6.51 \%$ & $-0.94 \%$ \\
\hline & & 0.54 & 0.88 & 0.69 & 0.97 & 0.14 & 0.54 & 0.27 & 0.46 \\
\hline \multirow[t]{2}{*}{2007} & 2009 & $40.40 \%$ & $3.20 \%$ & $43.39 \%$ & $3.10 \%$ & $6.76 \%$ & $4.13 \%$ & $36.63 \%$ & $-1.03 \%$ \\
\hline & & 0.42 & $<0.01 * * *$ & 0.43 & $<0.01 * * *$ & 0.18 & $0.02 * *$ & 0.50 & 0.80 \\
\hline \multirow[t]{2}{*}{2007} & 2010 & $3.80 \%$ & $4.60 \%$ & $-6.13 \%$ & $4.54 \%$ & $21.89 \%$ & $6.37 \%$ & $-28.02 \%$ & $-1.83 \%$ \\
\hline & & 0.65 & $<0.01 * * *$ & 0.50 & $<0.01 * * *$ & 0.16 & $0.01 * *$ & 0.11 & 0.54 \\
\hline \multicolumn{10}{|c|}{ Panel C: operating performance is measure by growth in sales } \\
\hline \multirow[t]{2}{*}{2007} & 2008 & $-3.30 \%$ & $0.10 \%$ & $-4.45 \%$ & $-1.76 \%$ & $9.01 \%$ & $17.43 \%$ & $-13.46 \%$ & $-19.19 \%$ \\
\hline & & 0.42 & 0.99 & 0.32 & 0.62 & 0.32 & 0.24 & 0.19 & 0.19 \\
\hline \multirow[t]{2}{*}{2007} & 2009 & $-12.90 \%$ & $-1.10 \%$ & $-14.11 \%$ & $-1.12 \%$ & $0.08 \%$ & $2.57 \%$ & $-14.19 \%$ & $-3.69 \%$ \\
\hline & & $0.01 * *$ & $0.09 *$ & $0.01 * *$ & $0.09^{*}$ & 0.99 & 0.88 & 0.20 & 0.69 \\
\hline \multirow[t]{2}{*}{2007} & 2010 & $-22.30 \%$ & $-9.60 \%$ & $-23.50 \%$ & $-9.69 \%$ & $-9.30 \%$ & $-1.00 \%$ & $-14.20 \%$ & $-8.69 \%$ \\
\hline & & $<0.01 * * *$ & $<0.01 * * *$ & $<0.01 * * *$ & $<0.01 * * *$ & 0.22 & 0.42 & 0.12 & 0.42 \\
\hline
\end{tabular}

Notes: ${ }^{*}, * * * *$ Significant at the 10,5 and 1 percent levels, respectively.

The evidence in Table 4 can be summarized as follows. First, decertification does not seem to be the result of differences in economic performance following the initial ISOcertification event. In effect, results show that both continuously certified and subsequently decertified companies in the sample enjoy a similar level of economic performance in the years that follow their initial ISO certification, a result that directly sheds light on our main

generated by the demise of Lheman Brothers. Yet, the design of this paper's event-study minimizes such criticism since the sample firms are carefully matched with other similar companies that have to compete in the exact same underlying economic setting. 
research question. Second, it is unclear how ISO certification affects the sample firm's overall performance. On the one hand, there is evidence to suggest that ISO-certification helps the newly certified firms to better use assets to generate operating profits, while leading to a significant reduction in the growth of sales rate. On the other hand, the same event does seem to boost cost-efficiency post-event. This paper tests the robustness of these conclusions in the next section.

\subsection{Robustness}

So far, this paper has employed the methodological choices that Barber \& Lyon (1996) show yield well-specified test statistics in all situations they consider. Yet, it is important to verify to what extent the previous findings are robust to reasonable methodological changes. The present section deals with this issue by resorting to two different methods for determining the control firms employed in the event-study.

The first is based on the findings of Barber \& Lyon (1996), who show that change models of expected performance that control for industry (2-digit SIC code) and pre-event performance (as measured by ROA) yield well-specified tests in samples of larger firms (see p.383). This seems like a sensible alternative to our base-case since Table 3 shows that this paper's sample firms are significantly larger than the population of comparable companies available in AMADEUS. ${ }^{5}$ The new match is conducted as follows. First, for each sample firm $i$, an initial set of match candidates is identified. Such candidates must have the same 2-digit SIC code of the sample firm two years before the event year, and a ROA figure that lies in the $90 \%$ to $110 \%$ interval of the ROA of sample firm $i$ in year $t-2$. Next, this paper checks whether each potential match candidate has all the required accounting data available on AMADEUS to conduct the event-study. Firms that do not comply with this data requirement are deleted. In the end, the alternative matching procedure now presented yields a different number of control firms per each firm $i$ in the sample. As such, following Barber \& Lyon (1996, p. 369), when appropriate, medians are used to proxy for the performance of the control group in year $t$.

The second robustness test draws on the work of Corbett et al. (2005). The authors investigate how ISO-certification affects firms' abnormal performance. Yet, unlike Barber \& Lyon (1996), Corbett et al. (2005) rely on one-to-one matching to compute their event-study results. Given some similarities between this paper and the work of Corbett et al. (2005), such alternative matching procedure is also employed to assess the robustness of the initial findings. In particular, all sample firms are matched with the firm in the same industry (2Digit SIC Code) that is 'closest' in terms of book value of assets and ROA. In line with Corbett et al. (2005), the matching procedure relies on z-scores of book-value of assets and ROA, which are computed by subtracting the industry mean and dividing by the industry standard deviation. The data employed to determine the z-score values for each firm is taken from the AMADEUS database two years before the event-year. Under this set up, 'closest' control firm is then defined as the firm with the smallest Euclidean distance in the twodimensional space of z-scores to the sample firm. Importantly, following Corbett et al. (2005), this paper also employs boundaries to the relative figures of size and ROA of the potential control firms. In particular, all candidates that in year $t-2$ have a ROA figure below (above) $90 \%(110 \%)$ of their corresponding sample firm are dropped from the analysis. Similarly, this paper does not consider match candidates that in year $t-2$ do not have a book value of assets inside the $50 \%$ to $200 \%$ relative to that of corresponding sample firm. Finally, match

\footnotetext{
${ }^{5}$ Considering models of abnormal performance that match control firms on lagged ROA and 2-digit SIC code, lagged ROA and 4-digit SIC code or lagged ROA and 2-digit SIC code and size yields essentially the same result. These are available on request from the authors.
} 
candidates that do not have all the necessary data on AMADEUS are deleted from the pool of potential control firms.

\subsection{Matching on Industry and ROA}

Table 5 summarizes the results of the first robustness tests. Panel A reports results when the control firms are matched using Industry and ROA. As can be seen, in line with the evidence presented in Table 4, Panel A of Table 5 suggests that the ISO certification event does not have an impact on how firms employ assets to generate operating income. In particular, none of the $t$ - and Wilcoxon signed-rank tests are significant at normal levels when the full sample is considered (i.e, "All firms" column). A similar result emerges when the sample is broken down into groups depending on whether the company decertifies in 2011 or not. Importantly, consistent with the evidence presented above, Panel A of Table 5 again shows that none of the Wilcoxon rank-sum test for differences in medians between ISO and Lost_ISO firms is significant at conventional levels.

Table 5. Robustness - Matching by Industry and ROA

\begin{tabular}{|c|c|c|c|c|c|c|c|c|c|}
\hline \multirow[b]{2}{*}{$\begin{array}{c}\text { Initial } \\
\text { Year }\end{array}$} & \multirow[b]{2}{*}{$\begin{array}{l}\text { Final } \\
\text { Year }\end{array}$} & \multicolumn{2}{|c|}{ All firms } & \multicolumn{2}{|c|}{ ISO Firms } & \multicolumn{2}{|c|}{ LOST_ISO Firms } & \multicolumn{2}{|c|}{ (ISO - LOST.) } \\
\hline & & $\begin{array}{c}\text { AP } \\
\text { Mean }\end{array}$ & $\begin{array}{c}\text { AP } \\
\text { Median }\end{array}$ & $\begin{array}{c}\text { AP } \\
\text { Mean }\end{array}$ & $\begin{array}{c}\text { AP } \\
\text { Median }\end{array}$ & $\begin{array}{c}\text { AP } \\
\text { Mean }\end{array}$ & $\begin{array}{c}\text { AP } \\
\text { Median }\end{array}$ & $\begin{array}{c}\text { AP } \\
\text { Mean }\end{array}$ & $\begin{array}{c}\text { AP } \\
\text { Median }\end{array}$ \\
\hline \multicolumn{10}{|c|}{ Panel A: operating performance is measure by ROA } \\
\hline \multirow[t]{2}{*}{2007} & 2008 & $-0.10 \%$ & $-0.10 \%$ & $0.11 \%$ & $0.18 \%$ & $-0.45 \%$ & $0.56 \%$ & $0.56 \%$ & $-0.38 \%$ \\
\hline & & 0.82 & 0.96 & 0.81 & 0.54 & 0.65 & 0.95 & 0.60 & 0.89 \\
\hline \multirow[t]{2}{*}{2007} & 2009 & $0.00 \%$ & $-0.30 \%$ & $-0.22 \%$ & $0.38 \%$ & $0.13 \%$ & $0.27 \%$ & $-0.35 \%$ & $0.11 \%$ \\
\hline & & 0.98 & 0.80 & 0.68 & 0.92 & 0.92 & 0.84 & 0.79 & 0.90 \\
\hline \multirow[t]{2}{*}{2007} & 2010 & $0.10 \%$ & $0.30 \%$ & $-0.24 \%$ & $0.03 \%$ & $-0.06 \%$ & $1.52 \%$ & $-0.18 \%$ & $-1.49 \%$ \\
\hline & & 0.87 & 0.58 & 0.73 & 0.91 & 0.95 & 0.30 & 0.87 & 0.57 \\
\hline \multicolumn{10}{|c|}{ Panel B: operating performance is measure by ROS } \\
\hline \multirow[t]{2}{*}{2007} & 2008 & $-0.10 \%$ & $0.50 \%$ & $1.22 \%$ & $0.17 \%$ & $7.73 \%$ & $1.11 \%$ & $-6.51 \%$ & $-0.94 \%$ \\
\hline & & 0.89 & 0.18 & 0.69 & 0.97 & 0.14 & 0.54 & 0.27 & 0.46 \\
\hline \multirow[t]{2}{*}{2007} & 2009 & $3.90 \%$ & $1.50 \%$ & $43.39 \%$ & $3.10 \%$ & $6.76 \%$ & $4.13 \%$ & $36.63 \%$ & $-1.03 \%$ \\
\hline & & 0.19 & $<0.01 * * *$ & 0.43 & $<0.01 * * *$ & 0.18 & $0.02 * *$ & 0.50 & 0.80 \\
\hline \multirow[t]{2}{*}{2007} & 2010 & $2.80 \%$ & $2.90 \%$ & $-6.13 \%$ & $4.54 \%$ & $21.89 \%$ & $6.37 \%$ & $-28.02 \%$ & $-1.83 \%$ \\
\hline & & 0.23 & $<0.01 * * *$ & 0.5 & $<0.01 * * *$ & 0.16 & $0.01 * *$ & 0.11 & 0.54 \\
\hline \multicolumn{10}{|c|}{ Panel C: operating performance is measure by growth in sales } \\
\hline \multirow[t]{2}{*}{2007} & 2008 & $-5.10 \%$ & $-0.60 \%$ & $-4.45 \%$ & $-1.76 \%$ & $9.01 \%$ & $17.43 \%$ & $-13.46 \%$ & $-19.19 \%$ \\
\hline & & 0.22 & 0.62 & 0.32 & 0.62 & 0.32 & 0.24 & 0.19 & 0.19 \\
\hline \multirow[t]{2}{*}{2007} & 2009 & $-9.80 \%$ & $-1.90 \%$ & $-14.11 \%$ & $-1.12 \%$ & $0.08 \%$ & $2.57 \%$ & $-14.19 \%$ & $-3.69 \%$ \\
\hline & & $0.02 * *$ & $0.05^{*}$ & $0.01 * *$ & $0.09 *$ & 0.99 & 0.88 & 0.20 & 0.69 \\
\hline \multirow[t]{2}{*}{2007} & 2010 & $-37.30 \%$ & $-5.80 \%$ & $-23.50 \%$ & $-9.69 \%$ & $-9.30 \%$ & $-1.00 \%$ & $-14.20 \%$ & $-8.69 \%$ \\
\hline & & $0.01 * *$ & $<0.01 * * *$ & $<0.01 * * *$ & $<0.01 * * *$ & 0.22 & 0.42 & 0.12 & 0.42 \\
\hline
\end{tabular}

Notes: ${ }^{*}{ }^{* *},{ }^{* *}$ Significant at the 10,5 and 1 percent levels, respectively.

Table 5 also shows what happens when ROS and growth in sales are employed as alternative performance metrics. Panel B summarizes the evidence for ROS. As can be seen, results suggest that ISO certification positively impacts the level of cost-efficiency of the sample firms. In fact, for the full sample, the median abnormal performance is $1.50 \%$ $(p<0.01)$ for the 2007-2009 period and is $2.90 \%(p<0.01)$ in the 2007-2010 window. Interestingly, Panel B of Table 5 shows that such result holds when the sample is divided into 
ISO and Lost_ISO companies. To be precise, for the former, median abnormal performance in $2007-2009$ is $3.10 \%(p<0.01)$ and is $4.54 \%(p<0.01)$ in 2007-2010. Matching results for the latter set are $4.13 \%(p=0.02)$ and $6.37 \%(p=0.01)$, respectively. Yet, very importantly, the evidence uncovered clearly suggests that the two groups of firms under analysis do not present significant differences in their cost-efficiency performance following their initial ISOcertification. In fact, once again, this paper is unable to find statistically significant Wilcoxon rank-sum test for differences in medians in this context.

Panel $\mathrm{C}$ of Table 5 refers to the results for growth in sales. Consistent with the findings in Table 4, there is clear evidence that ISO-certification leads to a decline in the growth of sales. To this point, the median (and mean) abnormal performance of the full sample is negative and significant at normal levels for both the 2007-2009 and the 2007-2010 eventperiods. Furthermore, in a clear parallel to what was discussed when presenting Table 4 above, this paper finds that only companies allocated to the ISO firms set experience very negative and significant variation in sales after receiving their initial certification. Indeed, for such firms, the median (mean) abnormal performance in the $2007-2009$ period is $-1.12 \%$ ($14.11 \%)$, significant at the $10 \%(1 \%)$ level. Results for the complementary 2007-2010 eventwindow are $-9.69 \%(p<0.01)$ and $-23.50 \%(p<0.01)$ for median and mean performance, respectively. Lost_ISO firms, however, exhibit a totally different performance pattern. In fact, for them, Panel $\overline{\mathrm{C}}$ of Table 5 shows parametric and non-parametric tests that yield nonsignificant $p$-values. Furthermore, noticeably, Panel $\mathrm{C}$ reveals that none of $t$ - or Wilcoxon rank-sum tests for difference is significant at normal levels. As such, under the alternative methodological set up under scrutiny, the empirical evidence again suggests that firms that continue certified in 2011 do not experience a statistically different rate in their growth in sales after receiving their initial ISO certification relative to that of comparable firms that lose such certification in that same year.

\subsection{One-to-one matching}

Table 6 presents the results of the second robustness test. Looking at Panel A, this paper again finds that none of the Wilcoxon signed-rank test and $t$-tests are significant even at the $10 \%$ level when ROA is the performance metric. Such conclusion holds for both the full sample and the ISO and Lost_ISO firms considered separately and does not depend on the particular event-period one considers. In addition, in this context, all parametric and nonparametric tests for differences in performance across the two groups of interest are not significant, which again suggests that decertification cannot be explained solely based on economic considerations.

Table 6 reports results when ROS is the performance metric in Panel B. As can be seen, for the full sample, none of the Wilcoxon signed-rank test is statistically significant even at the $10 \%$ level. Yet, the median abnormal performance of the ISO firms is positive and statistically significant at normal levels for both the 2007-2009 and 2007-2010 event windows, which suggest that the initial ISO-certification helps these firms improve their costto-sales performance over and above what one could expect given risk. Similar, albeit weaker evidence is uncovered for the Lost_ISO companies. For them, only the 2007-2010 eventwindow displays significant results (median $=3.87 \% ; \mathrm{p}=0.01$ ). A final note for the fact that the results reported in Panel B of Table 6 again shows that the different Wilcoxon rank-sum test for differences in medians between ISO and Lost_ISO firms are never significant at conventional levels. Such evidence again suggests that differences in performance following the initial ISO-certification cannot be used to explain why decertification occurs subsequently. 
Table 6. Robustness - One-to-one matching by Industry, size and ROA

\begin{tabular}{|c|c|c|c|c|c|c|c|c|c|}
\hline \multirow[b]{2}{*}{$\begin{array}{c}\text { Initial } \\
\text { Year }\end{array}$} & \multirow[b]{2}{*}{$\begin{array}{l}\text { Final } \\
\text { Year }\end{array}$} & \multicolumn{2}{|c|}{ All firms } & \multicolumn{2}{|c|}{ ISO Firms } & \multicolumn{2}{|c|}{ LOST_ISO Firms } & \multicolumn{2}{|c|}{ (ISO - LOST.) } \\
\hline & & $\begin{array}{c}\text { AP } \\
\text { Mean }\end{array}$ & $\begin{array}{c}\text { AP } \\
\text { Median }\end{array}$ & $\begin{array}{c}\text { AP } \\
\text { Mean }\end{array}$ & $\begin{array}{c}\text { AP } \\
\text { Median }\end{array}$ & $\begin{array}{c}\text { AP } \\
\text { Mean }\end{array}$ & $\begin{array}{c}\text { AP } \\
\text { Median }\end{array}$ & $\begin{array}{c}\text { AP } \\
\text { Mean }\end{array}$ & $\begin{array}{c}\text { AP } \\
\text { Median }\end{array}$ \\
\hline \multicolumn{10}{|c|}{ Panel A: operating performance is measure by ROA } \\
\hline \multirow[t]{2}{*}{2007} & 2008 & $0.10 \%$ & $-0.20 \%$ & $-0.03 \%$ & $-0.06 \%$ & $-0.86 \%$ & $-0.33 \%$ & $0.83 \%$ & $0.27 \%$ \\
\hline & & 0.92 & 0.62 & 0.94 & 0.87 & 0.42 & 0.72 & 0.48 & 0.58 \\
\hline \multirow[t]{2}{*}{2007} & 2009 & $0.80 \%$ & $-0.40 \%$ & $0.01 \%$ & $0.51 \%$ & $-0.24 \%$ & $-0.92 \%$ & $0.25 \%$ & $1.43 \%$ \\
\hline & & 0.43 & 0.39 & 0.99 & 0.66 & 0.87 & 0.55 & 0.87 & 0.51 \\
\hline \multirow[t]{2}{*}{2007} & 2010 & $-0.10 \%$ & $0.00 \%$ & $0.04 \%$ & $0.24 \%$ & $0.85 \%$ & $1.06 \%$ & $-0.81 \%$ & $-0.82 \%$ \\
\hline & & 0.87 & 0.69 & 0.96 & 0.74 & 0.45 & 0.24 & 0.53 & 0.52 \\
\hline \multicolumn{10}{|c|}{ Panel B: operating performance is measure by ROS } \\
\hline \multirow[t]{2}{*}{2007} & 2008 & $-8.10 \%$ & $-0.30 \%$ & $-0.32 \%$ & $0.43 \%$ & $2.13 \%$ & $0.47 \%$ & $-2.45 \%$ & $-0.04 \%$ \\
\hline & & 0.28 & 0.33 & 0.73 & 0.10 & 0.42 & 0.77 & 0.38 & 0.98 \\
\hline \multirow[t]{2}{*}{2007} & 2009 & $-3.00 \%$ & $-0.30 \%$ & $3.85 \%$ & $1.52 \%$ & $4.94 \%$ & $1.70 \%$ & $-1.09 \%$ & $-0.18 \%$ \\
\hline & & 0.51 & 0.52 & 0.12 & $<0.01 * * *$ & 0.20 & 0.12 & 0.81 & 0.63 \\
\hline \multirow[t]{2}{*}{2007} & 2010 & $-6.50 \%$ & $0.00 \%$ & $0.65 \%$ & $2.83 \%$ & $26.39 \%$ & $3.87 \%$ & $-25.74 \%$ & $-1.04 \%$ \\
\hline & & 0.24 & 0.78 & 0.76 & $<0.01 * * *$ & 0.1 & $0.01 * *$ & 0.12 & 0.19 \\
\hline \multicolumn{10}{|c|}{ Panel C: operating performance is measure by growth in sales } \\
\hline \multirow[t]{2}{*}{2007} & 2008 & $-4.80 \%$ & $0.30 \%$ & $-6.29 \%$ & $-1.73 \%$ & $8.36 \%$ & $10.78 \%$ & $-14.65 \%$ & $-12.51 \%$ \\
\hline & & 0.32 & 0.64 & 0.16 & 0.34 & 0.23 & 0.14 & 0.17 & 0.18 \\
\hline \multirow[t]{2}{*}{2007} & 2009 & $-6.30 \%$ & $-3.60 \%$ & $-10.88 \%$ & $-2.19 \%$ & $2.13 \%$ & $-1.40 \%$ & $-13.01 \%$ & $-0.79 \%$ \\
\hline & & $0.04 * *$ & $0.02 * *$ & $<0.01 * * *$ & $0.05^{*}$ & 0.80 & 0.75 & 0.16 & 0.82 \\
\hline \multirow[t]{2}{*}{2007} & 2010 & $-14.10 \%$ & $-5.20 \%$ & $-39.78 \%$ & $-5.81 \%$ & $-9.77 \%$ & $-5.52 \%$ & $-30.01 \%$ & $-0.29 \%$ \\
\hline & & $<0.01 * * *$ & $0.01 * *$ & $0.01 * *$ & $<0.01 * * *$ & 0.23 & 0.34 & 0.11 & 0.83 \\
\hline
\end{tabular}

Notes: ${ }^{*}{ }^{* *}, * * *$ Significant at the 10,5 and 1 percent levels, respectively.

Panel C of Table 6 also summarizes the evidence when growth in sales is employed as the performance metric. One again the reported results suggest that the ISO-certification event leads to a significant decline in the affected firms' sales growth rate. For full sample and event-period 2007-2009, the median (mean) abnormal performance is $-3.6 \%(-6.3 \%)$, significant at the 5\% (5\%) level. The corresponding value for the $2007-2010$ period is $-5.20 \%$ $(-14.10 \%)$, also significant at the five percent (better than the 1\%) level. Sample firms are, however, affected differently according to whether they ISO-decertify in 2011. Consistent with the evidence discussed above, a significant loss in growth in sales only occurs when companies keep their certification in the future since the remaining companies in the sample seem to exhibit an economic performance that is consistent with their level of risk. Once again, none of the parametric and non-parametric tests for differences in performance between ISO and Lost_ISO are statistically significant at normal levels. This evidence is in line with results reported above and leads to the same basic conclusion: firms that lose their certification in 2011 do not seem to experience difference performance level vis-à-vis that of their equivalent firms that continue ISO-certified after such date.

\section{Discussion, conclusion and implications}

A vast number of papers suggest that ISO 9001 certification has a positive effect on firm performance and that this impact accrues over time (e.g., Heras, Casadesús \& Dick, 2002; Corbett et al., 2005; Benner \& Veloso, 2008). However, the recent worldwide raise in the 
number of certification withdrawals (ISO, 2014) disputes these findings and highlights the need to understand the reasons behind this trend, an area virtually untapped in the literature.

The present paper directly addresses this issue and empirically explores whether subsequent decertification is driven by the lack of improvement in economic performance following the initial ISO certification event. This paper investigates this novel topic in the literature with the help of a sample of 278 Portuguese non-listed SMEs that obtained their initial ISO 9001 certification in 2008. The main findings can be summarized as follows. First, it is unlikely that ISO 9001 decertification can be explained for economic reasons. In particular, following the initial ISO-9001 certification, firms that subsequently decertify enjoy a level of economic performance that is not statistically different from that of comparable continuously ISO-certified companies. Such conclusion is robust to various measures of economic performance, numerous methods for accounting for risk, and different eventperiods. Second, it is unclear whether ISO certification really boosts economic performance. In fact, the empirical evidence suggests that such event does not help firms to improve how they employ assets to generate operating profits and it harms the growth rate in sales of the newly certified companies. Results, however, also show that companies become more costefficient once they become certified. Interestingly, these conclusions are not contingent on whether companies continue to be ISO-certified subsequently and are very robust to various event-study methods and economic performance metrics.

\subsection{Implications for theory}

This paper supplements the scant research addressing ISO certification withdrawal and, in a novel contribution to the literature, disputes the idea that firms' decision to decertify is driven by economic reasons (Lo \& Chang, 2007; Sansalvador \& Brotons, 2015). In particular, this paper's results show that ISO firms that are subsequently decertified exhibit a level of post-certification performance as measured by ROA, ROS and growth of sales that is comparable to that of companies that do not undergo the same decertification event. Hence, it is unlikely that companies that continue certified are the ones that collect economic benefits whilst those that withdraw their certification are the ones that do not benefit from the certification event.

Second, the results of this paper suggest that the decision to renew or withdraw from the ISO certification is economically irrelevant. There are at least two possible explanations for the phenomenon. First, ISO certification is no longer economically interesting as a result of the large and increasing number of certified firms, which would seat well with the predictions of the resource-based theory. Under its set up, a competitive advantage can be achieved through possession of resources that are valuable, rare, inimitable and conveniently managed (Barney \& Clark, 2007). In that respect, ISO registration may be perceived as a valuable resource (Cândido et al., 2016) that could provide certified firms with a competitive advantage. Yet, ISO certification has become very popular in some industries, which questions its rareness and difficulty to imitate. As such, the sheer number of issued ISO certificates in some sectors might contribute to a dilution of the competitive advantage provided by certification. Thus, in a rational world, companies would continue certified only until the point where the competitive advantage (and the economic benefits) is compensated by their certification costs. That is apparently the point that has been reached. The recent revision of the ISO 9001 standard might contribute to change this situation, but the actual effects of such change will have to be accessed by further research. The second reason that may explain why the renewal or withdrawal of the ISO certification is economically irrelevant relates to how firms internalize the benefits of the ISO certification (Cândido et al., 2016). In general, most firms should benefit from implementing the ISO 9001 certificate as such process impacts many different aspects of how the business is organized and conducted. Yet, 
after the initial three years of certification, such effects may simply disappear. This would be the case if the certification benefits are fully internalized within such a period or when the expected future benefits of continuing ISO certified are simply not enough to justify a renewal of the certificate.

\subsection{Implications for the ISO 9001 Governance System}

This paper results are particularly relevant to the more than one million certified companies that every three years must choose whether to renew or to withdraw from ISO 9001 certification. It can be argued that part of these companies might not even consider the withdrawal option, but many others must balance the renewal costs and future benefits in their decision process leading up to the renewal/withdrawal decision. This study clarifies what is involved in that decision and its possible consequences, which, on average, are not significant in terms of economic performance. However, to a given individual firm, the (ir)relevancy of the decision to renew or decertify can strongly depend on factors such as the motivations leading up to the initial certification, culture of quality acquired, top management involvement, industry of the company contemplating the renewal decision, number of certified competitors, and other factors. For example, if the motivation leading up to certification was customer request, the decision to renew or decertify must consider any changes in that factor.

This study has implications for other members of the ISO 9001 governance system (Castka et al., 2015) as well. Certification bodies are facing an increase in the number of withdrawn certificates (reduction in renewals) and the standards setting organization (ISO) a stagnation in the number of companies adopting its most important standard. Certification renewal seems to have become irrelevant from an economic point of view, which means that ISO and certification bodies must create conditions to fight this irrelevancy. Cost of opportunity (e.g. lost contracts) and non-economic benefits probably explain why the majority of certified companies still renew their certificates, but in order to continue to grow in size, the ISO 9001 governance system needs to change. Such change must address an increase in the economic benefits of certification for all certified companies. Building on Terziovski and Guerrero (2014), Castka et al. (2015), and Eriksson et al. (2016), this study results suggest also that the ISO governance system should become a catalyst for change, recognizing firmspecific implementation of the ISO 9001 standard, to help creating sustainable competitive advantage.

\subsection{Limitations and suggestions for further research}

The conclusions and implications of this paper must be read with caution as they are drawn from a small sample of Portuguese firms that were ISO 9001 certified in 2008. This is a particular setting to explore this paper's main research question since Portugal faced severe economic distress at that time, which led to an intervention by the International Monetary Fund, the European Union, and the European Central Bank in 2011. Although this paper's methodology explicitly accounts for this issue, as both sample and control firms experienced identical environmental conditions, further research could help understand to what extent this paper's findings hold in different macroeconomic settings. This study does not address emerging issues such as preparation for certification (Esgarrancho \& Cândido, 2017), fraud in certification processes (Kafel \& Nowicki, 2014), and other issues such as implementation obstacles (Cândido \& Santos, 2019), and quality assessment (Cândido, 2005; Santos \& Cândido, 2016; Tinoco, Cândido \& Feliciano, 2017), which might have an impact on ISO implementation and may be considered in future research. Given the lack of research on the certification withdrawal domain, more studies are necessary to continue to clarify this issue, both in similar and dissimilar contexts to the ones in this research and with identical and different research methods. 


\section{Acknowledgment}

The authors wish to thank two anonymous reviewers for their insightful comments and helpful suggestions. The authors also wish to thank Jennifer Nicole Elston and Carina Ramos Jesus for their help.

\section{Funding}

This paper is financed by National Funds of the FCT - Portuguese Foundation for Science and Technology within the project «UID/ECO/04007/2019».

\section{Disclosure statement}

No potential conflict of interest was reported by the authors.

\section{ORCID}

Carlos J.F. Cândido: http://orcid.org/0000-0001-5875-1243

Luís M.S. Coelho: http://orcid.org/0000-0002-8074-4194

Rúben M.T. Peixinho: https://orcid.org/0000-0003-4178-3008

\section{Research Gate:}

Carlos J.F. Cândido: https://www.researchgate.net/profile/Carlos_Candido2

Luís M.S. Coelho: https://www.researchgate.net/profile/Luis_Coelho12

Rúben M.T. Peixinho: https://www.researchgate.net/profile/Ruben_Peixinho

\section{References}

Aba, E.K., Badar, M.A, \& Hayden, M.A. (2016). Impact of ISO 9001 certification on firms financial operating performance. International Journal of Quality and Reliability Management, 33(1), 78-89.

Alič, M. (2014) Impact of ISO 9001 certification cancellation on business performance: A case study in Slovenian organizations. Total Quality Management, 25(7), 790-811.

Asquith, P., Healy, P. \& Palepu, K. (1989). Earnings and stock splits. The Accounting Review, 64(3), 387-403.

Barber, B. \& Lyon, J. (1996). Detecting abnormal operating performance: The empirical power and specification of test statistics. Journal of Financial Economics, 41(3), 359399.

Barney, J.B. \& Clark, D.N. (2007), Resource-Based Theory, Oxford University, Oxford.

Benner, M.J. \& Veloso, F.M. (2008). ISO 9000 practices and financial performance: A technology coherence perspective. Journal of Operations Management, 26(5), 611-629.

Cândido, C.J.F. (2005). Service quality strategy implementation: A model and the case of the Algarve hotel industry. Total Quality Management \& Business Excellence, 16(1), 3-14

Cândido, C.J.F. \& Santos, S.P. (2019). Implementation obstacles and strategy implementation failure. Baltic Journal of Management, 14(1), 39-57.

Cândido, C.J.F., Coelho, L.M.S. \& Peixinho, R.M.T. (2016). The financial impact of a withdrawn ISO 9001 Certificate. International Journal of Operations \& Production Management, 36(1), 23-41.

Castka, P., Prajogo, D., Sohal, A. \& Yeung, A.C.L. (2015). Understanding firms' selection of their ISO 9000 third-party certifiers. International journal of Production Economics, 162, 
$125-133$.

Chatzoglou, P., Chatzoudes, D. \& Kipraios, N. (2015). The impact of ISO 9000 certification on firms' financial performance. International Journal of Operations \& Production Management, 35(1), 145-174.

Chow-Chua, C., Goh, M. \& Wan, T.B. (2003). Does ISO 9000 certification improve business performance? International Journal of Quality \& Reliability Management, 20(8), 936953.

Corbett, C.J., Montes-Sancho, M.J. \& Kirsch, D.A. (2005). The financial impact of ISO 9000 Certification in the United States: An empirical analysis. Management Science, 51(7), 1046-1059.

Dick, G.P.M., Heras, I. \& Casadesús, M. (2008). Shedding light on causation between ISO 9001 and improved business performance. International Journal of Operations \& Production Management, 28(7-8), 687-708.

Eriksson, H., Gremyr, I., Bergquist, B., Garvare, R., Fundin, A., Wiklund, H., Wester, M., and Sörqvist, L. (2016). Exploring quality challenges and the validity of excellence models. International Journal of Operations \& Production Management, 36(10), 12011221.

Esgarrancho, S. \& Cândido, C.J.F. (2017) Firm preparation for ISO 9001 Certification: The case of the hotel industry in Portugal. Total Quality Management \& Business Excellence. http://dx.doi.org/10.1080/14783363.2017.1404428

Fatima, M. (2014). Impact of ISO 9000 on business performance in Pakistan: Implications for quality in developing countries. Quality Management Journal, 21(1), 16-24.

Gómez, J.M., Fontalvo, T.J. \& Vergara, J.C. (2013). Incidencia de la certificación ISO 9001 en los indicadores de productividad y utilidad financiera de empresas de la zona industrial de Mamonal en Cartagena. Estudios Gerenciales, 29(126), 99-109.

Healy, P. \& Palepu, K. (1988). Earnings information conveyed by dividend initiations and omissions. Journal of Financial Economics, 21(2), 149-176.

Healy, P. \& Palepu, K. (1990). Earnings and risk changes surrounding primary stock offers. Journal of Accounting Research, 28(1), 25-48.

Heras, I., Casadesús, M. \& Dick, G.P.M. (2002). ISO 9000 certification and the bottom line: a comparative study of the profitability of Basque region companies. Managerial Auditing Journal, 17(1/2), 72-78.

Islam, M.M., Habes, E., Karim, A. \& Agil, S.O.S. (2016). Quality certification and company performance - The newly developed country experience. Journal of Business Economics and Management, 17(4), 628-644.

ISO (2012). The ISO Survey of Management System Standard Certifications - 2011: Executive Summary. Genève: ISO Central Secretariat.

ISO (2014). The ISO survey of Management System Standard Certifications - 2013: Executive Summary. Genève: ISO Central Secretariat.

Kafel, P. \& Nowicki, P. (2014). Functioning of environmental and quality management systems after resignation of management standard certification: Case study of Polish organisations. International Journal for Quality Research, 8(4), 505-516.

Lo, L.K. \& Chang, D.S. (2007). The difference in perceived benefits between firms that 
maintain ISO certification and those that do not, International Journal of Production Research, 48(5), 1881-1897.

Miller, S., Jayaram, J. \& Xu, K. (2018). Obtaining global certification: Analysis of ownership structures and TQM commitment in emerging markets by adapting the theory of planned behaviour. International Journal of Operations \& Production Management, https://doi.org/10.1108/IJOPM-03-2017-0155.

Mokhtar, M.Z., Karbhari, Y. \& Naser, K. (2005). Company financial performance and ISO 9000 registration: Evidence from Malaysia. Asia Pacific Business Review, 11(3), 349-367.

Nair, A. \& Prajogo, D. (2009). Internalisation of ISO 9000 standards: The antecedent role of functionalist and institutionalist drivers and performance implications. International Journal of Production Research, 47(16), 4545-4568.

Naveh, E. \& Marcus, A. (2005). Achieving competitive advantage through implementing a replicable management standard: Installing and using ISO 9000. Journal of Operations Management, 24(1), 1-26.

Naveh, E. \& Marcus, A.A. (2007). Financial performance, ISO 9000 standard and safe driving practices effects in accident rate in the U.S motor carrier industry. Accident Analysis and Prevention, 39(4), 731-742.

Ochieng, J., Muturi, D. \& Njihia, S.N. (2015). The impact of ISO 9001 implementation on organizational performance in Kenya. The TQM Journal, 27(6), 761-771.

Pantouvakis, A. \& Dimas, A. (2010). Does ISO 9000 series certification matter for the financial performance of ports? Some preliminary findings from Europe. Maritime Policy \& Management, 37(5), 505-522.

Prajogo, D.I. (2011). The roles of firms' motives in affecting the outcomes of ISO 9000 adoption. International Journal of Operations \& Production Management, 31(1), 78-100.

Psomas, E., Pantouvakis, A. \& Kafetzopoulos, D. (2013). The impact of ISO 9001 effectiveness on the performance of service companies. Managing Service Quality, 23(2), 149-164.

Psomas, E. \& Kafetzopoulos, D. (2014). Performance measures of ISO 9001 certified and non-certified manufacturing companies. Benchmarking, 21(5), 756 - 774.

Sansalvador, M.E. \& Brotons, J.M. (2015) Valuation of the option of abandoning ISO 9001 certification: An empirical study in Spain, Total Quality Management, 26(12), 12551268 .

Santos, A.H.M. \& Cândido, C.J.F. (2016). Avaliação da qualidade dos serviços bancários online: Proposta de integração dos modelos SERVQUAL, Kano e QFD. Tourism \& Management Studies, 12(2), 145-153.

Simmons, B.L. \& White, M.A. (1999). The relationship between ISO 9000 and business performance: Does registration really matter? Journal of Managerial Issues, 11(3), 330344.

Simon, A. \& Kafel, P. (2018). Reasons for decertification of ISO 9001: An empirical study. Innovar, 28(70), 69-80.

Tinoco, P.C.R., Cândido, C.J.F. \& Feliciano, I.M.P.L. (2017). A importância da avaliação da qualidade percebida em radiologia e o impacto dos fatores sociodemográficos num hospital público português. Portuguese Journal of Public Health, 35(3), 202-213. 
Terziovski, M. \& Guerrero, J.-L. (2014). ISO 9000 quality system certification and its impact on product and process innovation performance. International Journal of Production Economics, 158, 197-207. 